\title{
2-methyloxolane as alternative solvent for lipid extraction and its effect on the cactus (Opuntia ficus-indica L.) seed oil fractions ${ }^{\text {is }}$
}

\author{
Said Gharby ${ }^{1, *}$, Harish Karthikeyan Ravi $^{2}$, Dominique Guillaume ${ }^{3}$, Maryline Abert Vian ${ }^{2}$, \\ Farid Chemat ${ }^{2, *}$ and Zoubida Charrouf ${ }^{4}$ \\ ${ }^{1}$ Laboratory Biotechnology, Materials and Environment (LBME), Faculty Poly disciplinary of Taroudant, \\ University Ibn Zohr, Taroudant, Morocco \\ 2 Avignon University, INRAE, UMR 408, GREEN Extraction Team, 84000 Avignon, France \\ 3 Université de Reims-Champagne Ardenne, CNRS, UMR 7312, Faculté de Pharmacie, 51100 Reims, France \\ ${ }^{4}$ Laboratory of Plant Chemistry and Organic and Bioorganic Synthesis, Faculty of Sciences, Mohammed V University, Rabat, Morocco
}

Received 7 March 2020 - Accepted 6 April 2020

\begin{abstract}
The potential of 2-methyloxolane (2-MeO) as an alternative solvent to extract cactus seed oil was compared, in qualitative and quantitative terms, with that of n-hexane, a solvent commonly used for the extraction of edible or cosmetic oils. With 2-MeO, the oil yield was higher $(9.55 \pm 0.12 \mathrm{~g} / 100 \mathrm{~g})$ than the oil extracted with $\mathrm{n}$-hexane $(8.86 \pm 0.25 \mathrm{~g} / 100 \mathrm{~g})$. The chemical and physical parameters quality indices (acidity, peroxide value and extinction coefficients $\left(\mathrm{K}_{232}\right.$ and $\left.\mathrm{K}_{270}\right)$ of 2-methyloxolane extracted oil were found to be much higher than that of oil extracted with n-hexane. A suitable refining scheme will have to be applied, probably leading to slight additional cost and losses. Also, the results showed that the sterol content was higher in the oil obtained with $2-\mathrm{MeO}(111.5 \pm 2.5 \mathrm{mg} / 100 \mathrm{~g})$ as a solvent when compared to the oil extracted with nhexane $(102.1 \pm 7.54 \mathrm{mg} / 100 \mathrm{~g})$. However, fatty acid and tocopherol content were not influenced by the extraction solvent. Therefore, the bio-based solvent 2-methyloxolane can be considered as an excellent alternative to the petroleum-based solvent n-hexane for edible/cosmetic oil extraction. The utilization of 2-MeO for oil extraction can drastically reduce the health and environmental impacts associated with n-hexane.
\end{abstract}

Keywords: lipid extraction / 2-methyloxolane / safety / cactus oil / chemical quality

Résumé - 2-methyloxolane comme solvant alternatif pour l'extraction des lipides et son effet sur les fractions d'huile de graines de cactus (Opuntia ficus-indica L.). Le potentiel du 2-méthyloxolane (2$\mathrm{MeO}$ ) comme solvant alternatif pour l'extraction de l'huile de graines de cactus a été comparé, en termes qualitatifs et quantitatifs, à celui du n-hexane, un solvant couramment utilisé pour l'extraction des huiles alimentaires ou cosmétiques. Avec le 2-MeO, le rendement en huile est plus élevé $(9,55 \pm 0,12 \mathrm{~g} / 100 \mathrm{~g})$ que celui de l'huile extraite avec le n-hexane $(8,86 \pm 0,25 \mathrm{~g} / 100 \mathrm{~g})$. Les indices de qualité des paramètres chimiques et physiques (acidité, indice de peroxyde et coefficients d'extinction $\left(\mathrm{K}_{232}\right.$ et $\left.\mathrm{K}_{270}\right)$ de l'huile extraite au 2-méthyloxolane ont été comparés avec ceux de l'huile extraite au n-hexane. De plus, les résultats ont montré que la teneur en stérols était plus élevée dans l'huile obtenue avec le 2-MeO (111,5 $\pm 2,5 \mathrm{mg} /$ $100 \mathrm{~g}$ ) comme solvant par rapport à l'huile extraite avec le n-hexane $(102,1 \pm 7,54 \mathrm{mg} / 100 \mathrm{~g})$. Cependant, la teneur en acides gras et en tocophérols n'a pas été influencée par le solvant d'extraction. Par conséquent, le 2-méthyloxolane, solvant d'origine végétale, peut être considéré comme une excellente alternative au nhexane, solvant à base de pétrole, pour l'extraction des huiles alimentaires/cosmétiques. L'utilisation du 2 $\mathrm{MeO}$ pour l'extraction peut réduire considérablement les impacts environnementaux associés au n-hexane.

Mots clés : lipide / extraction / 2-methyloxolane / figuier de barbarie / huile

\footnotetext{
it Contribution to the Topical Issue "Technological challenges in oilseed crushing and refining / Défis technologiques de la trituration et du raffinage des oléagineux".

*Correspondences: s.gharby@yahoo.fr;

farid.chemat@univ-avignon.fr
} 


\section{Introduction}

Cosmetic vegetable oils are particularly valued by customers because of their remarkable moisturizing, and more generally their characteristic dermatologic properties. Their natural origin makes cosmetic vegetable oils an environment-friendly product and is preferred by customers. Argan, shea, olive and almond oils constitute just a few examples of vegetable oils successfully introduced in a wide range of cosmetics. Recently, cactus (Opuntia ficus-Indica L.) seed oil has been presented as a new ingredient able to penetrate, and quickly find its place, in the field of the highvalue cosmetic ingredients primarily due to its specific chemical composition ideal for cosmetic applications (Guillaume et al., 2015; Taoufik et al., 2015). At present, the market price of the cactus seed oil is estimated to be $500 € / \mathrm{L}$.

Cactus fruit (prickly pear) contains numerous seeds, around 300 seeds per fruit (Barbera et al., 1994) that was initially considered as waste by the food industry. However, cactus seeds can be valorized by recovering their oil. Literature data suggest that the oil processed from the seeds constitutes $7-15 \%$ of whole seed weight and is characterised by a high degree of unsaturation where linoleic acid $(56.1-77 \%)$ is the primary fatty acid (Ramadan and Mörsel, 2003). The yield of cactus seed oil can reach $6.5 \%$ when seeds are cold-pressed, although some variability depending on the seed geographical origin has been reported (Ciriminna et al., 2017). The remaining press-cake is still oil-rich, and extraction of oil from crushed seeds with hexane enhances cactus seed oil yield. The obtained yield with solvent extraction is 50 to $75 \%$ higher than that obtained with presses (Mouden et al., 2012). The solvent hexane has long been touted as a solvent of choice for lipid extraction due to the subsequent oil recovery easiness, lipid specificity, low latent heat of vaporization leading to limited solvent regeneration costs and very low water miscibility allowing the use of steam stripping for solvent removal which is efficient in terms of solvents residues in oil and meals, solvent losses, and processing cost, relatively narrow boiling point and its excellent lipid solubilizing ability (Fine et al., 2013; Kumar et al., 2017; Tanzi et al., 2012; Ravi et al., 2019). However, the use of hexane raises some environmental concerns (Fine et al., 2013; Kumar et al., 2017) and oil mills using hexane are classified as "SEVESO low threshold" pertaining to the solvent toxicity. Recent studies on green solvents for the extraction of oil from oilseeds and other natural biomass revealed that 2-MeO could be considered as the best choice among other available bio-based solvents (Sicaire et al., 2014, Sicaire et al., 2015, Ravi et al., 2019). Indeed, 2-MeO is produced from renewable raw materials, and it is biodegradable, presenting a promising environmental footprint. The toxicological aspects of 2-MeO are likely to be less harmful than hexane (Antonucci et al., 2011; Ravi et al., 2019).

This research work attempts to shed light on the selection of an alternative solvent for delipidification of plant biomass. The principal parameters of the oil fractions extracted were compared with the reference solvent. The objective of this work was to identify a green solvent that could serve as a potential replacement to hexane. The solvent 2-methyloxolane (2-MeO) was selected for this purpose based on literature review, industrial-scale availability, and its ecological footprint. The efficacy of 2-MeO as a suitable replacement to the conventional solvent was probed by comparing various parameters such as oil yield, lipid class composition, quality indices, fatty acid profile, sterol composition and tocopherols content.

\section{Materials and methods}

\subsection{Raw material, standards and reagents}

Cactus seeds were sourced from the local market in Agadir, Morocco. The raw material was milled in a Blixer 2 (Robot coupe) apparatus and was sieved through a $2 \mathrm{~mm}$ mesh screen and subjected to oil extraction. The initial moisture content of the powdered material was $3.54 \pm 0.78 \%$, and the raw material was stored at ambient temperature in a sealed pouch. $2-\mathrm{MeO}$ and standards used for chromatography analyses were from Sigma-Aldrich Co, St. Louis (MO, USA). Other solvents were of analytical grade and purchased from VWR international (Darmstadt, Germany).

\subsection{Lipid extraction}

A soxhlet system was used to extract the lipids from cactus seed powder. For de-oiling of the biomass, n-hexane and 2$\mathrm{MeO}$ were used as extraction solvent with a solid to solvent ratio of $1: 10$. The extraction was carried out for $8 \mathrm{~h}$. The solvent was evaporated under reduced pressure in a rotavapor. The oil was purged with nitrogen and stored at $-18^{\circ} \mathrm{C}$ until further analysis and extraction yield (oil) was calculated gravimetrically.

\subsection{Chemical and physical oil parameters}

The chemical and physical parameters such as acidity index, peroxide value and extinction coefficients $\left(\mathrm{K}_{232}\right.$ and $\left.\mathrm{K}_{270}\right)$ were analyzed based on the analytical methods described in Regulations EC 2568/91 (European Commission Regulation, $\mathrm{EEC} / 2568 / 91,2003)$. Acidity was expressed as the oleic (C18:1) acidity in the mass percentage of oil. Peroxide index was expressed as milliequivalents of active oxygen per kilogram of oil (Meq $\mathrm{O}_{2} / \mathrm{kg}$ oil), and extinction coefficient $\mathrm{K}_{232}$ and $\mathrm{K}_{270}$ were expressed as the specific extinctions of a $1 \%(\mathrm{w} / \mathrm{v})$ solution of oil in cyclohexane measured in a $10 \mathrm{~mm}$ cuvette, using a SCILOGEX SP- UV1100 spectrometer. The iodine value (IV) was computed from FAME percentages using the formula: $\mathrm{IV}=(\%$ palmitoleic $\times 1.001)+(\%$ oleic $\times 0.899)+(\%$ linoleic $\times 1.814)+(\%$ linolenic $\times 2.737)($ Gharby et al., 2018).

\subsection{Fatty acid composition}

The fatty acid composition was determined using the International Organization for Standardization method ISO 12966-2 (2011). Before analysis, fatty acids (FAs) were converted to fatty acid methyl esters (FAMEs) by shaking a solution of $60 \mathrm{mg}$ oil and $3 \mathrm{~mL}$ of hexane with $0.3 \mathrm{~mL}$ of $2 \mathrm{~N}$ methanolic potassium hydroxide for $25 \mathrm{~min}$.

The fatty acid composition was determined as their corresponding methyl esters by gas chromatography (Agilent6890) coupled with a flame ionization detector (GC-FID).

The capillary column CP-Wax $52 \mathrm{CB}(30 \mathrm{~m} \times 250 \mu \mathrm{m}$ i.d., $0.25 \mu \mathrm{m}$ film thickness) was used. The carrier gas was helium, 
and the total gas flow rate was $1 \mathrm{~mL} / \mathrm{min}$. The initial oven temperature was $170{ }^{\circ} \mathrm{C}$, the final temperature $230{ }^{\circ} \mathrm{C}$, and the temperature gradient was $4^{\circ} \mathrm{C} / \mathrm{min}$. Injector and detector temperature were set at $220^{\circ} \mathrm{C}$. The injection volume of the samples was $2 \mu \mathrm{L}$ in a split mode (split ratio 1:50). The results were expressed as the relative percentage of the area of each fatty acid peaks.

\subsection{Sterol composition}

The sterol composition was determined using the International Standard Organization method. Sterol composition was determined after trimethylsilylation of the crude sterol fraction using a Varian 3800 instrument equipped with a VF-1, column ( $30 \mathrm{~m}$ and $0.25 \mathrm{~mm}$ i.d.) and using helium (flow rate $1.6 \mathrm{~mL} / \mathrm{min}$ ) as the carrier gas. The column temperature was isothermal at $270^{\circ} \mathrm{C}$, injector and detector temperature was $300^{\circ} \mathrm{C}$. The injection volume was $1 \mu \mathrm{l}$ for each analysis.

\subsection{High-Performance Thin Layer Chromatography (HPTLC)}

\subsubsection{Standard, sample solutions and plate pre-treatment}

All samples $(1 \mathrm{mg} / \mathrm{mL})$ and standards $(0.2 \mathrm{mg} / \mathrm{mL})$ were dissolved in chloroform and stored in the dark at $20^{\circ} \mathrm{C}$. A mixture of chloroform/methanol $(2: 1, \mathrm{v} / \mathrm{v})$ was used for the pre-development of HPTLC plates (silica gel 60 F254). This step was followed by drying the plates at $110^{\circ} \mathrm{C}$ for $60 \mathrm{~min}$ on a TLC plate heater (CAMAG, Switzerland).

\subsubsection{Neutral and polar lipid analyses}

Lipid extracts were spotted on to $20 \times 10 \mathrm{~cm}$ silica gel 60 $\mathrm{F}_{254}$ HPTLC plates with an ATS 5 automatic TLC sampler. The development of the plates was accomplished with a mixture of solvent acting as a mobile phase for elution using an ADC 2 automatic development chamber (CAMAG).

For neutral lipids, the mobile phase comprised of n-hexane/ diethyl ether/glacial acetic acid in a ratio of $35: 15: 1 ; \mathrm{v} / \mathrm{v} / \mathrm{v}$ (Ravi et al., 2018).

In case of polar lipids, the mobile phase system was a mixture of methyl acetate/ISOpropanol/chloroform/methanol/ $\mathrm{KCl}(0.25 \%$ solution $)$ in a ratio of $25: 25: 25: 10: 9 \mathrm{v} / \mathrm{v} / \mathrm{v} / \mathrm{v} / \mathrm{v}$. The elution height was $7 \mathrm{~cm}$ from the origin (spot position) for both the plates. Finally, the plates were dipped in a reagent $(10 \mathrm{mg}$ primuline, $160 \mathrm{~mL}$ acetone, $40 \mathrm{~mL} \mathrm{H}_{2} \mathrm{O}$ ) for visualization, derivatization, and quantitation executed using a TLC scanner 3 equipped with WinCATs software (CAMAG).

\subsection{Tocopherols composition}

The tocopherols composition was determined using the International Standard Organization method. High-performance liquid chromatography (HPLC) was used for the determination of tocopherols, the supernatant from a solution prepared by mixing $250 \mathrm{mg}$ of oil in $25 \mathrm{~mL}$ of $\mathrm{n}-$ heptane was used for quantitation in a Shimadzu CR8AHPLC instrument (Champ Sur Marne, France) equipped with a C18Varian column $(25 \mathrm{~cm} \times 4 \mathrm{~mm}$; Varian Inc., Middelburg,
Netherlands). Detection was performed using a fluorescence detector (excitation wavelength $290 \mathrm{~nm}$, detection wavelength $330 \mathrm{~nm}$ ). The eluent used was a 99:1 isooctane/ isopropanol $(\mathrm{V} / \mathrm{V})$ mixture at a flow rate of $1.2 \mathrm{~mL} / \mathrm{min}$.

\subsection{Data analysis}

Analysis of variance (ANOVA), one-way ANOVA was carried out for the experimental data with normality assumptions using XLSTAT v2019.1 statistical software (Addinsoft, New York, NY). Post hoc test Turkey's HSD was applied to evaluate significant difference among the means of different groups $(n=2)$ and $p<0.05$ was considered significant.

\section{Results and discussion}

\subsection{Oil yield and lipid class composition}

The yields of cactus seed oil extracted with n-hexane and 2$\mathrm{MeO}$ was $8.86 \pm 0.25 \%$ and $9.55 \pm 0.12 \%$ respectively. Such higher yield observed for the 2-MeO extraction is not surprising considering that the solubilizing properties of $2-\mathrm{MeO}$ are better partly due to the higher polarity of the 2-MeO than n-hexane. Nevertheless, the composition of the extract had to be determined to make sure that 2-MeO had not dissolved undesired substances. Regarding lipid class composition, the obtained results reveal that the (TAG) triglycerides were the largest neutral lipid class among the two oils compared, accounting for almost $100 \%$ in the n-hexane and $92 \%$ in the $2-$ $\mathrm{MeO}$ lipid fraction (Fig. 1b). Free fatty acid (FFA) was found in the 2-MeO oil fraction, which could be due to selective extraction of FFA by 2-MeO. Also, pure n-hexane is known for being less efficient in the extraction of FFA. Authors, Ayers and Dooley (1948) and Arnold and Choudhury (1960) indicated that the rate of oil extraction by pure n-hexane is slower than that of less pure hexane when extracting soybeans, but was found to equal when extracting oil from cottonseed. Also, the purer hexane extracted less free fatty acids and fewer color pigments from both Indeed, a trace amount of ergosterol was found in the $2-\mathrm{MeO}$ oil fraction but they were below the minimum quantitation limit. However, the polar lipids particularly phospholipids, were not present in both oils extracted using the solvent n-hexane and 2-MeO (Fig. 1c). Generally, owing to its high polarity 2-MeO can extract freely available polar lipid constituents. Previously reported values of phospholipids content in cactus seed oil was $70.7 \pm 4.55 \mathrm{~g} / \mathrm{kg}$ of total lipids (Ramadan and Mörsel, 2003). The absence of polar lipids in the extracted cactus seed oil could be due to improper grinding, which limits the solvents ability to leach out molecules of interest or non-homogenous sampling of oil for analysis.

\subsection{Chemical and physical parameters quality indices}

The primary quality indices (acidity, PV, $\mathrm{K}_{232}, \mathrm{~K}_{270}$ and iodine value) of each oil are presented in Table 1 . The amount of free fatty acid is a parameter that reflects edible oil quality and is traditionally used as an indicator for the classification of the different commercial types of virgin oil like argan and olive oil (SNIMA, 2003; COI, 2013; Gharby et al., 2018). The 2$\mathrm{MeO}$ oil exhibited an acidity index of $3.02 \pm 0.5$, which was relatively higher than the acidity index of oil extracted with 


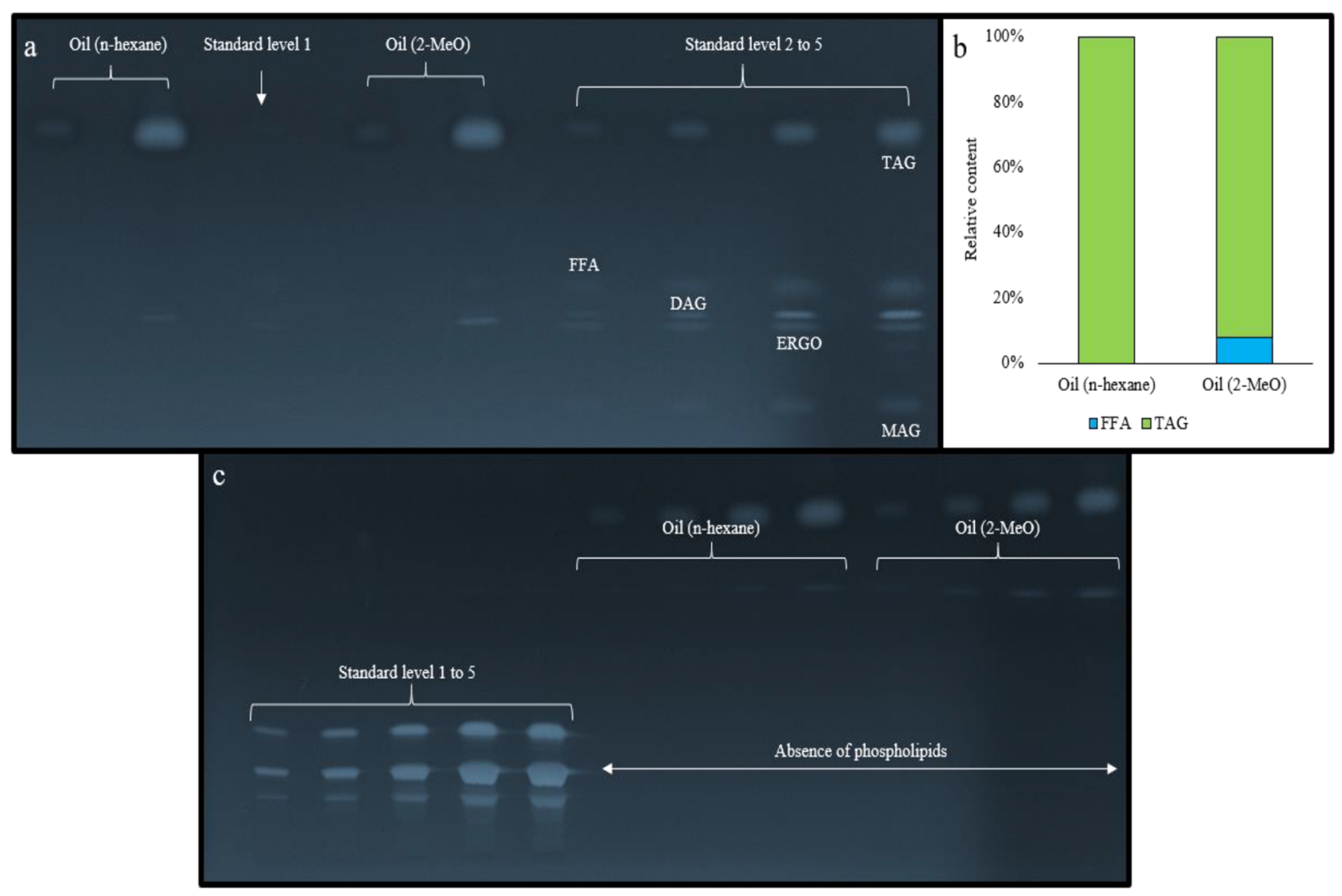

Fig. 1. a: HPTLC plate of neutral lipids; b: relative content of neutral lipids; c: HPTLC plate of polar lipids.

Table 1. Quality characteristics of the crude oil extracted with nhexane and 2-MeO.

\begin{tabular}{lcc}
\hline Description & Oil (n-hexane) & Oil $(2-\mathrm{MeO})$ \\
\hline Yield oil $(\mathrm{g} / 100 \mathrm{~g})$ & $8.86 \pm 0.25^{\mathrm{b}}$ & $9.55 \pm 0.12^{\mathrm{a}}$ \\
Acidity $(\mathrm{g} / 100 \mathrm{~g})$ & $1.26 \pm 0.5^{\mathrm{b}}$ & $3.02 \pm 0.5^{\mathrm{a}}$ \\
Peroxide value $\left(\mathrm{Meq} . \mathrm{O}_{2} / \mathrm{kg}\right)$ & $3.5 \pm 1.5^{\mathrm{b}}$ & $8.6 \pm 2.5^{\mathrm{a}}$ \\
$\mathrm{K}_{232}$ & $2.75 \pm 0.5^{\mathrm{a}}$ & $3.25 \pm 0.5^{\mathrm{a}}$ \\
$\mathrm{K}_{270}$ & $0.51 \pm 0.5^{\mathrm{b}}$ & $2.11 \pm 0.5^{\mathrm{a}}$ \\
Iodine index $\left[\mathrm{I}_{2} / 100 \mathrm{~g}\right]$ & $131.5 \pm 0.5^{\mathrm{a}}$ & $132 \pm 0.3^{\mathrm{a}}$ \\
\hline
\end{tabular}

Results are expressed as average \pm standard deviation $(n=3)$; Values with same superscript letters within the rows do not differ significantly $(p<0.05)$.

$n$-hexane $(1.26 \pm 0.5)$. The increase in acidity index of oil extracted with $2-\mathrm{MeO}$ can be attributed to the selective extraction of FFA by 2-MeO solvent as discussed above.

Lipid oxidation decreases the quality of the oil, thereby limiting oil shelf life. Indeed, the peroxide value (PV) evaluates the hydroperoxide content, and it is considered to be an indicator of primary oxidation. High peroxide value (PV) is generally associated with fat rancidity, but the PV threshold depends on the fat material (Harhar et al., 2010). The two oils considered here showed high PV values, with the 2-MeO extracted oil demonstrated the highest value with $8.6 \mathrm{MeqO}_{2} / \mathrm{kg}$.
Generally, commercial-grade 2-MeO are stabilized with an antioxidant to inhibit the peroxidation of the solvent. In the case of 2-MeO, butylated hydroxytoluene (BHT) is added to the solvent $(2.5 \mathrm{~L})$ usually within a range of 150 to $400 \mathrm{ppm}$. In some cases $\alpha$-tocopherol is also used for this purpose. The high operational temperature in the Soxhlet apparatus during oil extraction might degrade the antioxidants, inevitably promoting the oxidation of the solvent and subsequently altering the peroxide value of the extracted oil. Another aspect that could lead to oxidation is when the solvent is evaporated under reduced pressure in the rotavapor system, the temperature set in the water bath is around $40^{\circ} \mathrm{C}$ for $2-\mathrm{MeO}$ as the boiling point of $2-\mathrm{MeO}$ is close to $80^{\circ} \mathrm{C}$, this could lead to hydrolysis of triglycerides and might oxidize the oil to an extent. Extinction co-efficient is another quality index that can be used to evaluate the presence of primary $\left(\mathrm{K}_{232}\right)$ or secondary $\left(\mathrm{K}_{270}\right)$ oxidation products. Accordingly, with peroxide value, extinction coefficients $\left(\mathrm{K}_{232}\right.$ and $\left.\mathrm{K}_{270}\right)$ of 2-MeO extracted were found to be higher than those of hexane-extracted crude oil, confirming a higher oxidative state for oil extracted with 2-MeO. High chemical and physical parameters quality indices of these oils suggested that both oils should be further refined before using it.

Indeed, the oil obtained using solvent extraction is generally refined before consumption to remove impurities like free fatty acids (acidity) and oxidation products (Yorulmaz, 2018). More data on the oxidative stability of cactus seed oil is necessary for understanding the oil stability, studies like oxipres and rancimat could be used for the determination of oxidative stability of oils. 
Table 2. Relative percentage of fatty acid profiles of cactus seed oil.

\begin{tabular}{lcr}
\hline Fatty acid (\%) & Oil (n-hexane) & Oil (2-MeO) \\
\hline Myristic acid [C14:0] & $0.10 \pm 0.01^{\mathrm{a}}$ & $0.09 \pm 0.01^{\mathrm{a}}$ \\
Palmitic acid [C16:0] & $11.75 \pm 0.02^{\mathrm{a}}$ & $11.70 \pm 0.14^{\mathrm{a}}$ \\
Stearic acid [C18:0] & $3.28 \pm 0.01^{\mathrm{a}}$ & $3.14 \pm 0.05^{\mathrm{a}}$ \\
Arachidic acid [C20:0] & $0.33 \pm 0.01^{\mathrm{a}}$ & $0.30 \pm 0.01^{\mathrm{b}}$ \\
Margaric acid [C17:0] & $0.06 \pm 0.01^{\mathrm{a}}$ & $0.06 \pm 0.01^{\mathrm{a}}$ \\
$\Sigma$ SFA & $15.52 \pm 0.25^{\mathrm{a}}$ & $15.29 \pm 0.10^{\mathrm{a}}$ \\
Palmitoleic acid [C16:1] & $0.75 \pm 0.01^{\mathrm{a}}$ & $0.76 \pm 0.01^{\mathrm{a}}$ \\
Heptadecenoic acid [C17:1] & $0.02 \pm 0.01^{\mathrm{a}}$ & $0.02 \pm 0.01^{\mathrm{a}}$ \\
Oleic acid [C18:1] & $21.22 \pm 0.03^{\mathrm{b}}$ & $20.95 \pm 0.12^{\mathrm{a}}$ \\
Eicosenoic acid [C20:1] & $0.35 \pm 0.01^{\mathrm{a}}$ & $0.33 \pm 0.01^{\mathrm{a}}$ \\
$\Sigma$ MUFA & $22.34 \pm 0.5^{\mathrm{a}}$ & $22.06 \pm 0.2^{\mathrm{a}}$ \\
Linoleic acid [C18:2] & $61.52 \pm 0.09^{\mathrm{a}}$ & $61.67 \pm 0.24^{\mathrm{a}}$ \\
Linolenic acid [C18:3] & $0.25 \pm 0.05^{\mathrm{a}}$ & $0.3 \pm 0.05^{\mathrm{a}}$ \\
$\Sigma$ PUFA & $61.77 \pm 0.5^{\mathrm{a}}$ & $62.27 \pm 0.5^{\mathrm{a}}$ \\
Others & $0.10 \pm 0.01^{\mathrm{a}}$ & $0.09 \pm 0.01^{\mathrm{a}}$ \\
\hline SFA-Satuted &
\end{tabular}

SFA-Saturated Fatty acids, MUFA-Monounsaturated fatty acids, PUFA-Polyunsaturated fatty acids. Results are expressed as average \pm standard deviation $(n=3)$; Values with same superscript letters within the rows do not differ significantly $(p<0.05)$.

\subsection{Fatty acid composition}

The composition of fatty acid is an essential indicator of the nutritional value of oil (Gharby et al., 2018). Cactus oil is particularly rich in unsaturated fatty acids and is very well documented (El Mannoubi et al., 2009; Matthäus and Özcan, 2011; Taoufik et al., 2015). Table 2 shows the results of the relative percentage of fatty acids cactus seed oil extracted with 2-MeO and n-hexane.

Fatty acid composition of oil extracted with both the solvents were similar, and fatty acid content was found to be in the range of previously published values for cactus seed oil from Morocco (Zine et al., 2013; Taoufik et al., 2015; Gharby et al., 2020) and other countries reported in the literature including Turkish (Matthäus and Özcan, 2011), Italian (Loizzo et al., 2019) and Tunisian seed oils (El Mannoubi et al., 2009). Linoleic acid a polyunsaturated fatty acid was the major fatty acid constituting up to $62 \%$ of the fatty acid content. The cumulative unsaturated fatty acids content was almost $84 \%$ thus making the cactus seed oil a rich source of unsaturated fatty acids and enhancing its usability for various purposes in cosmetic and food industries alike.

Linolenic acid is only a minor component with a concentration of less than $0.3 \%$. The diminished content of this fatty acid can be used to detect the adulteration of cactus oil with other oils rich in linolenic acids such as rapeseed oil and soybean oil.

Cactus oil also contains two primary saturated fatty acids: palmitic acid (11.70-11.75\%) and stearic acid (3.14-3.28\%). Other fatty acids such as arachidic acid (C20:0), margaric acid (C17:0), myristic acid (C14:0) and palmitoleic acid (C16:1) were found only in relatively lower quantities. The extraction solvent employed for the defatting does not tend influence the fatty acid profile (Ravi et al., 2019). Our results confirm the excellent balance of cactus oil fatty acids obtained with $2-\mathrm{MeO}$.
Table 3. Sterol content of (mg/100 g) of cactus seed oil.

\begin{tabular}{lrr}
\hline Sterols $[\mathrm{mg} / 100 \mathrm{~g}]$ & Oil (n-hexane) & Oil $(2-\mathrm{MeO})$ \\
\hline Cholesterol & $1.76 \pm 0.38^{\mathrm{a}}$ & $1.52 \pm 0.39^{\mathrm{a}}$ \\
Campesterol & $11.61 \pm 0.12^{\mathrm{b}}$ & $12.26 \pm 0.13^{\mathrm{a}}$ \\
Stigmasterol & $3.29 \pm 0.03^{\mathrm{a}}$ & $3.36 \pm 0.53^{\mathrm{a}}$ \\
$\beta$-Sitosterol & $75.56 \pm 0.67^{\mathrm{b}}$ & $82.82 \pm 0.74^{\mathrm{a}}$ \\
$\Delta$-5-Avenasterol & $4.37 \pm 0.06^{\mathrm{a}}$ & $4.07 \pm 0.07^{\mathrm{b}}$ \\
$\Delta$-7-Stigmasterol & $1.75 \pm 0.02^{\mathrm{b}}$ & $2.17 \pm 0.02^{\mathrm{a}}$ \\
$\Delta$-7-Avenasterol & $2.00 \pm 0.03^{\mathrm{b}}$ & $2.17 \pm 0.02^{\mathrm{a}}$ \\
Total sterol & $102.1 \pm 5.54^{\mathrm{a}}$ & $111.5 \pm 2.5^{\mathrm{a}}$ \\
\hline
\end{tabular}

Results are expressed as average \pm standard deviation $(n=3)$; Values with same superscript letters within the rows do not differ significantly $(p<0.05)$.

To get a better picture of the unsaturated fatty acids content in the oil, the iodine value was determined. Both the oils possessed similar iodine value (131-132 $\mathrm{g}$ of $\mathrm{I}_{2} / 100 \mathrm{~g}$ ) (Tab. 1) suggesting a similar unsaturated fatty acid (UFA) composition which was concurrent with previously reported values in cactus oil (Zine et al., 2013; Taoufik et al., 2015). So high iodine value indicated high unsaturated fatty acids content of both oils. Therefore, a high level of unsaturated fatty acid in vegetable oil is essential for its preservation and pharmacological activity (Khallouki et al., 2003).

\subsection{Sterol composition}

Among the sterols $\beta$-sitosterol and campesterol were found to be the major components of cactus seed oil. On the other hand, the minor sterols were cholesterol, $\Delta 5$-avenasterol, $\Delta 7$ stigmasterol, $\Delta 7$-avenasterol (Gharby et al., 2020). Concerning the relative percentage of sterols distribution in oil extracted with n-hexane and 2-MeO, no significant differences were observed. Generally, all phytosterols composition in both the oils was found to be satisfactory and within the range of published values for cactus seed oil from Morocco (Zine et al., 2013; Taoufik et al., 2015). However, the oil extracted with 2$\mathrm{MeO}(111.5 \pm 2.5 \mathrm{mg} / 100 \mathrm{~g})$ had higher total sterol content than the oil extracted with n-hexane $(102.1 \pm 7.54 \mathrm{mg} / 100 \mathrm{~g})$ (Tab. 3).

\subsection{Tocopherols composition}

Tocopherols are minor and vital components of the unsaponifiable fraction in vegetable oils (Gharby et al., 2018). This family of compounds is considered highly bioactive natural antioxidants with various degrees of effectiveness (Guillaume and Charrouf, 2011; Gharby et al., 2020). There are four different types of tocopherols that can be identified in the lipid fraction of oilseeds. The $\gamma$-tocopherol is the principal tocopherol present in cactus oil with a relative percentage of almost $87 \%$ to tocopherols fraction, $\alpha$ and $\delta$ tocopherols were present in lower quantities making up the rest $13 \%$ of the tocopherols composition.

However, cactus seed oil does not contain $\beta$-tocopherol (El Mannoubi et al., 2009; Taoufik et al., 2015). As reflected in 
Table 4. Tocopherols content of (mg/100 g) of cactus seed oil.

\begin{tabular}{lcc}
\hline Tocopherols $[\mathrm{mg} / 100 \mathrm{~g}]$ & Oil $(\mathrm{n}$-hexane) & Oil $(2-\mathrm{MeO})$ \\
\hline$\alpha$-tocopherol & $1.75 \pm 0.50^{\mathrm{a}}$ & $1.95 \pm 0.50^{\mathrm{a}}$ \\
$\beta$-tocopherol & N.D. & N.D. \\
$\gamma$-tocopherol & $68.4 \pm 0.50^{\mathrm{a}}$ & $67.46 \pm 0.50^{\mathrm{a}}$ \\
$\delta$-tocopherol & $7.5 \pm 0.50^{\mathrm{a}}$ & $8.26 \pm 0.50^{\mathrm{a}}$ \\
Total tocopherol & $78.75 \pm 0.50^{\mathrm{a}}$ & $77.85 \pm 0.50^{\mathrm{a}}$ \\
\hline
\end{tabular}

N.D.: Not detected. Results are expressed as average \pm standard deviation $(n=3)$; Values with same superscript letters within the rows do not differ significantly $(p<0.05)$.

Table 4, no significant differences between the hexane and 2$\mathrm{MeO}$ extracted oils were found for the content of individual tocopherols $(\gamma, \delta$ and $\alpha$-tocopherol). Indeed, the major tocopherol distribution was similar in oil samples extracted using the solvent $\mathrm{n}$-hexane and 2-MeO (68.4 and $67.46 \mathrm{mg} /$ $100 \mathrm{~g})$ respectively, compared with $\delta$-tocopherol $(7.5$ and $8.26 \mathrm{mg} / 100 \mathrm{~g}$ ) and $\alpha$-tocopherol $(1.75$ and $1.95 \mathrm{mg} / 100 \mathrm{~g})$. We also observed the absence of the $\beta$-tocopherol in both oils. The cumulative tocopherols content was $78.75 \mathrm{mg} / 100 \mathrm{~g}$, $77.85 \mathrm{mg} / 100 \mathrm{~g}$ for oil extracted with $\mathrm{n}$-hexane and $2-\mathrm{MeO}$ respectively. In general, the total tocopherols content of cactus oil is higher than that of extra virgin olive oil but lower than other edible vegetable oils (Zine et al., 2013; Taoufik et al., 2015).

\section{Conclusion}

The present results indicate that this study shows that the solvent 2-methyloxolane (2-MeO) an be considered as an excellent alternative to hexane for edible/cosmetic cactus oil extraction. Ecocert recognizes the solvent 2-MeO as suitable to produce COSMOS ingredients. Therefore, its use is allowed for the organic oils in cosmetics whereas hexane is forbidden. However, the oil extracted with hexane or 2-methyloxolane (2-MeO) should be further refined and more data on the mechanism of oxidation of cactus seed oils have to be probed for its successful incorporation in cosmetic formulations.

\section{References}

Antonucci V, Coleman J, Ferry JB, et al. 2011. Toxicological assessment of 2-methyltetrahydrofuran and cyclopentyl methyl ether in support of their use in pharmaceutical chemical process development. Organ Process Res Develop 15: 939-941.

Arnold LK, Choudhury RBR. 1960. Extraction of soybean and cottonseed oil by four solvents. J Am Oil Chem Soc 37(9): $458-459$.

Ayers AL, Dooley JJ. 1948. Laboratory extraction of cottonseed with various petroleum hydrocarbons. J Am Oil Chem Soc 25(10): 372-379.

Barbera G, Inglese P, La Mantia T. 1994. Seed content and fruit characteristics in cactus pear (Opuntia ficus-indica Miller). Sci Hortic 58: 161-165.

Ciriminna R, Delisi R, Albanese L, Meneguzzo F, Pagliaro M. 2017. Opuntia ficus-indica seed oil: Biorefinery and bioeconomy aspects. Eur J Lipid Sci Technol 119(8): 1700013.
El Mannoubi I, Barrek S, Skanji T, Casabianca H, Zarrouk H. 2009. Characterization of Opuntia ficus indica seed oil from Tunisia. Chem Nat Compd 45(5): 616-620.

European Commission Regulation EEC/2568/91. 2003. Regulation $2568 / 91$ on the characteristics of olive oil and olive-residue oil and on relevant methods of analysis and later amendments. Annex II: determination of acidity value. Annex III: determination of peroxide index. Annex IX: spectrophotometric test of UV absorption. Off J Eur Commun 1248: 1-109.

Fine F, Vian MA, Tixier ASF, Carre P, Pages X, Chemat F. 2013. Les agro-solvants pour l'extraction des huiles végétales issues de graines oléagineuses. OCL 20(5): A502.

Gharby S, Harhar H, Farssi M, Taleb AA, Guillaume D, Laknifli A. 2018. Influence of roasting olive fruit on the chemical composition and polycyclic aromatic hydrocarbon content of olive oil. OCL 25(3): A303.

Gharby S, Guillaume D, Nounah I, et al. 2020. Shelf life of Moroccan prickly pear (Opuntia ficus-indica) and argan (Argania spinosa) oils: a comparative study. Grasas Aceites 72(1): e397. https://doi. org/10.3989/gya.1147192.

Guillaume D, Charrouf Z. 2011. Argan oil and other argan products: Use in dermocosmetology. Eur J Lipid Sci Technol 113(4): 403-408.

Guillaume D, Gharby S, Harhar H, Baba M. 2015. Opuntia ficus indica and Balanites aegytiaca oils: two seed oils to watch. Househ Personal Care Today 10(2): 45-48.

Harhar H, Gharby S, Guillaume D, Charrouf Z. 2010. Effect of argan kernel storage conditions on argan oil quality. Eur J Lipid Sci Technol 112: 915-920.

ISO 12966-2. 2011. Corps gras d'origines animale et végétaleChromatographie en phase gazeuse des esters méthyliques d'acides gras-Partie 2: préparation des esters méthyliques d'acides gras.

Khallouki FY, Younos C, Soulimani R, et al. 2003. Consumption of argan oil (Morocco) with its unique profile of fatty acids, tocopherols, squalene, sterols and phenolic compounds should confer valuable cancer chemopreventive effects. Eur J Cancer Prevent 12(1): 67-75.

Kumar SPJ, Prasad SR, Banerjee R, Agarwal DK, Kulkarni KS, Ramesh KV. 2017. Green solvents and technologies for oil extraction from oilseeds. Chem Cent J 11(9): 1-7.

Loizzo MR, Bruno M, Balzano M, et al. 2019. Comparative chemical composition and bioactivity of Opuntia ficus-indica Sanguigna and Surfarina seed oils obtained by traditional andultra soundassisted extraction procedures. Eur J Lipid Sci Technol 121: 1-7.

Matthäus B, Özcan MM. 2011. Habitat effects on yield, fatty acid composition and tocopherol contents of prickly pear (Opuntiaficus-indica L.) seed oils. Sci Hortic 131: 95-98.

Mouden M, Boujnah M, Barki M, Rakib EM, Badoc A, Douira A. 2012. Effet de deux méthodes d'extraction et de la période de récolte sur le rendement en huile des graines de figue de Barbarie. Bull Soc Pharm Bordeaux 151: 7-14.

Norme commercial applicable aux huiles d'olive et aux huiles de Grignond'olive. COI/T.15/Nc n³/Rév. 7. 2013.

Ramadan MF, Mörsel JT. 2003. Oil cactus pear (Opuntia ficus-indica L.). Food Chem 82: 339-345.

Ravi HK, Breil C, Vian MA, Chemat F, Venskutonis PR. 2018. Biorefining of bilberry (vaccinium myrtillus L.) pomace using microwave hydrodiffusion and gravity, ultrasound-assisted, and bead-milling extraction. ACS Sustain Chem Eng 6: 4185-4193.

Ravi HK, Abert Vian M, Tao Y, et al. 2019. Alternative solvents for lipid extraction and their effect on protein quality in black soldier fly (Hermetiaillucens) larvae. J Clean Prod 238: 117861. 
Service de Normalisation Industrielle Marocaine (SNIMA). 2003. Huiles d'argane spécifications. Norme marocaine NM 08.5.090. Rabat: SNIMA.

Sicaire AG, Vian M, Filly A, Ying L, Bily A, Chemat F. 2014. 2Methyltetrahydrofuran: Main properties, production processes, and application in extraction of natural products. In: Alternative solvents for natural products extraction. Heidelberg, Berlin: Springer, pp. 253-268.

Sicaire AG, Vian M, Fine F, et al. 2015. Alternative bio-based solvents for extraction of fat and oils: solubility prediction, global yield, extraction kinetics, chemical composition and cost of manufacturing. Int J Mol Sci 16(4): 8430-8453.
Tanzi CD, Vian MA, Ginies C, Elmaataoui M, Chemat F. 2012. Terpenes as green solvents for extraction of oil from microalgae. Molecules 17(7): 8196-8205.

Taoufik F, Zine S, El Hadek M, et al. 2015. Oil content and main constituents of cactus seed oils Opuntia Ficus Indica of different origin in Morocco. Mediterr J Nutr Metab 8(2): 85-92.

Yorulmaz A. 2018. Influence of industrial refining on some characteristics of olive pomace oil. Rivista Italiana delle Sostanze Grasse 95(3): 167-172.

Zine S, Gharby S, El Hadek M. 2013. Physicochemical characterization of Opuntia ficus indica seed oil from Morocco. Biosci Biotechnol Res Asia 10(1): 99-105.

Cite this article as: Gharby S, Ravi HK, Guillaume D, Vian MA, Chemat F, Charrouf Z. 2020. 2-methyloxolane as alternative solvent for lipid extraction and its effect on the cactus (Opuntia ficus-indica L.) seed oil fractions. OCL 27: 27. 